\title{
Nutritive value of the proteins of Bengal gram of high and low protein content*
}

\author{
BY G. C. ESH, T. S. DE AND U. P. BASU \\ Bengal Immunity Research Institute, Calcutta 16, India \\ (Received 23 November 1959-Revised 21 April 1960)
}

It has been reported earlier (Esh, De \& Basu, 1959) that a $38 \%$ variation occurs in the protein content of the pulse, Bengal gram (Cicer arietinum), as a result of difference in genetic strain. Moreover, samples of Bengal gram were found to contain on the dry basis from 17.5 to $27.9 \%$ crude protein, when they were grown in different localities and from different strains (Esh et al. 1959). Varying results for the digestibility, biological value and growth-promoting value of the same variety of pulse protein have occasionally been reported by different investigators (Niyogi, Narayan \& Desai, I932 $a, b$; Basu, Nath \& Mukherjee, I937; Esh \& Som, 1952). To what extent this variation in the nutritive value can be attributed to the difference in protein content is not known. The literature, however, records significant variation in the overall nutritive value (Mitchell, Hamilton \& Beedles, 1952; Ross, Garrigus, Hamilton \& Earley, 1952; Sauberlich, Chang \& Salmon, 1953a; Hogan, Gillespie, Koçtürk, O'Dell \& Flynn, 1955) and amino-acid composition (Hansen, Brimhall \& Sprague, 1946; Sauberlich et al. 1953b) of proteins of high- and low-protein maize when grown from different genetic strains and in different environments with or without fertilizers.

In view of these findings, the nutritive values of proteins of high- and low-protein Bengal gram were studied in order to observe the effect, if any, of increase in protein content due to difference in genetic constitution, to environment in which they had been grown, or to both.

\section{EXPERIMENT AL}

\section{Samples}

Samples of Bengal gram of markedly high or low protein content were selected. They were collected from different State Agricultural Farms where they were raised from seeds of pure strains under controlled conditions. The strains of the samples used and the environmental conditions under which they were grown are shown in Table r.

\section{Animals}

Albino rats, bred and reared in our breeding colony under controlled conditions, were used, weanling ones weighing $45^{-} 5^{\circ} \mathrm{g}$ for the measurement of protein efficiency ratio and adult ones weighing $200-220 \mathrm{~g}$ for the balance-sheet method.

* Read in part before the Physiology Section of the Indian Science Congress Session held at Delhi in January 1959 . The paper is part 2 of a series of studies on pulse proteins, part 1 of which was published in Science (1959), 129, 148. 


\section{Balance-sheet method}

\section{Biological tests}

Digestibility and biological value were determined by the balance-sheet method of Mitchell (1923-4) and Mitchell \& Carman (1926). Seven samples of Bengal gram, of high or low protein content, were selected for the balance-sheet experiment. The samples were incorporated in the diet given to different groups of six adult albino rats at a $12 \%$ protein level. The experimental rations for these metabolism studies contained $12 \%$ hydrogenated fat, $4 \%$ U.S.P. XIV salt mixture no. $2,2 \%$ cod-liver oil,

Table I. Strains of the Bengal gram samples used in this investigation and the environmental conditions in which they were grown

\begin{tabular}{|c|c|c|c|c|c|c|}
\hline \multirow[b]{2}{*}{$\begin{array}{c}\text { Sample } \\
\text { no. }\end{array}$} & \multirow[b]{2}{*}{$\begin{array}{l}\text { Moisture } \\
\text { content } \\
(\%)\end{array}$} & \multirow{2}{*}{$\begin{array}{c}\text { Protein } \\
\text { content } \\
(\mathrm{N} \times 6 \cdot 25) \\
\text { on moisture- } \\
\text { free basis } \\
(\%)\end{array}$} & \multirow[b]{2}{*}{ Strain } & \multirow[b]{2}{*}{ Locality } & \multicolumn{2}{|c|}{ Environmental conditions } \\
\hline & & & & & $\begin{array}{c}\text { Annual } \\
\text { rainfall } \\
(\mathrm{cm})\end{array}$ & $\begin{array}{c}\text { Nature of } \\
\text { soil }\end{array}$ \\
\hline $\mathbf{I}$ & IO'I & $17 \cdot 5$ & D8 & Nagpur & $100-120$ & Black cotton \\
\hline 2 & $8 \cdot 4$ & 17.9 & Pink 2 & Ujjain & $80-90$ & Black cotton \\
\hline 3 & $9 \cdot 5$ & $19 \cdot 7$ & I.P.I. 707 & Indore & $90-100$ & Black cotton \\
\hline 4 & $9 \cdot 6$ & $20 \circ 0$ & Chafa & Niphad & $50-60$ & Black cotton \\
\hline 5 & $9 \cdot 5$ & $22 \cdot 0$ & Mut. I & Ujjain & $80-90$ & Black cotton \\
\hline 6 & 10.9 & $22 \cdot 7$ & T. 87 & Berhampur & $120-140$ & Alluvial \\
\hline 7 & 10.9 & $26 \cdot 3$ & No. 98 & Berhampur & $120-140$ & Alluvial \\
\hline 8 & $10 \cdot 5$ & $26 \cdot 8$ & Chafa & Junagadh & $60-70$ & Black cotton \\
\hline 9 & $10 \cdot 0$ & $27 \cdot 7$ & T. 87 & Kanpur & $75^{-80}$ & Alluvial \\
\hline 10 & 10.0 & $27 \cdot 9$ & Select no. Io & Berhampur & $120-140$ & Alluvial \\
\hline
\end{tabular}

$10 \%$ cane sugar, vitamin mixtures, the test pulse to supply $12 \%$ protein, and starch to give $100 \%$. The vitamin mixtures were: $(a)$ thiamine hydrochloride $20 \mathrm{mg}$, riboflavin $30 \mathrm{mg}$, nicotinic acid $200 \mathrm{mg}$, pyridoxine hydrochloride $12.5 \mathrm{mg}$, panthenol (pantothenic acid alcohol) $150 \mathrm{mg}$, folic acid $5 \mathrm{mg}$ and biotin $0.5 \mathrm{mg}$, dissolved in $50 \mathrm{ml}$ alcohol; and $(b) \alpha$-tocopherol $1000 \mathrm{mg}$ and menaphthone $20 \mathrm{mg}$ dissolved in $100 \mathrm{ml}$ arachis oil. Of the first mixture $\mathrm{I} \mathrm{ml}$, and of the second $0.5 \mathrm{ml}$, were added to each $100 \mathrm{~g}$ of the diet.

\section{Protein efficiency ratio}

Three sets of experiments were done with Bengal gram as the sole source of protein, or supplemented with wheat or casein.

Expt (a), pulse as sole source of protein. Four samples of Bengal gram, two of high and two of low protein content, were given to four groups of rats as sole source of dietary protein at the $12 \%$ protein level.

Expt (b), pulse supplemented with wheat. A constant quantity of wheat (contributing $5 \%$ protein in the diet) was added as a protein supplement to diets containing different amounts of Bengal gram of high or low protein content, so that the total protein content of the diet was $12 \%$ (see Table 4 ). In order to get the best gain in weight, the 
four pulse samples of high or low protein content were autoclaved to destroy their antitrypsin activity.

Expt (c), pulse supplemented with casein. The nutritive value of pulse samples supplemented with casein was tested by the technique used by Dobbins, Krider, Hamilton, Earley \& Terrill (1950a,b), and Mitchell et al. (1952) in their assessment of the nutritional quality of high- and low-protein maize. Three Bengal gram samples with $\mathrm{I} 7.5,22 \cdot 0$ or $26.5 \%$ protein were examined, supplemented with casein containing $79 \cdot 1 \%$ protein. Diets A, B and C contained a constant proportion of Bengal gram with enough casein to bring the protein content to $18 \%$. Another group of animals was fed on diet D, containing the same quantity of casein as diet A (see Table 5) and sufficient of the low-protein gram sample no. I to bring the protein content to $18 \%$.

Procedure. The diets were given for 3 weeks to weanling litter-mate rats, 28 days old, from our breeding colony, distributed in similar groups of six (three males and three females) and housed in individual screen-bottom metal cages with food and distilled water available $a d$ lib. The composition of the diets was essentially the same as used by Esh \& Som (1952). The basal diet contained $9 \%$ hydrogenated fat, $4 \%$ U.S.P. XIV salt mixture no. 2, 2\% cod-liver oil, vitamin mixtures and maize starch to give $100 \%$. The different experimental rations were made by replacing starch with the requisite quantity of pulse powder, pulse powder supplemented with wheat or pulse powder supplemented with casein, as shown in Tables $3^{-5}$ respectively. The animals were weighed twice a week. Since under certain dietary conditions, particularly with proteins of unbalanced amino-acid composition, the fat and nitrogen contents of the liver deviate from the normal, these constituents were estimated in groups of animals fed on supplemented diets. Liver fat was estimated by the method of Hawk, Edgar \& Elvehjem (1953) and liver nitrogen by a micro-Kjeldahl method.

In Expts $(a)$ and $(b)$ only two diets, one containing high-protein pulse and the other low-protein pulse, were compared at a time. In Expt $(c)$ comparisons were made between different pairs of diets. The experiments were so designed that all groups of rats compared were balanced with respect to litter composition and sex. The standard deviations given in each table do not serve for testing the significance of diet differences, but are included simply to describe the spread of values obtained on each treatment.

\section{RESULTS}

\section{Digestibility and biological value}

Digestibility, biological value and net protein value of the pulses are shown in Table 2.

The results show that proteins in almost all the high-protein samples had a slightly higher digestibility and slightly lower biological value than those in low-protein samples. The net protein values of all the high-protein samples, however, tended to be higher than those of low-protein pulses. 


\section{Protein efficiency ratio}

Expt (a). The results are shown in Table 3. It will be noted that with the pulses of high protein content higher protein efficiency ratios (P.E.R.'s) were obtained than with the low-protein pulses, indicating the superior nutritional quality of high-protein Bengal gram.

Table 2. Mean values with their standard deviations for true digestibility coefficient and biological value of samples of Bengal gram of low and high protein content, measured at the $12 \%$ level of protein intake

(Mean values for groups of six rats)

\begin{tabular}{|c|c|c|c|c|}
\hline $\begin{array}{l}\text { Pulse } \\
\text { sample } \\
\text { no. }\end{array}$ & $\begin{array}{c}\text { Protein content } \\
(\mathrm{N} \times 6.25) \\
\text { on moisture- } \\
\text { free basis } \\
(\%)\end{array}$ & $\begin{array}{l}\text { True digestibility } \\
\text { coefficient } \\
\text { (D.c.) }\end{array}$ & $\begin{array}{l}\text { Biological } \\
\text { value } \\
\text { (B.v.) }\end{array}$ & $\begin{array}{c}\text { Net protein value } \\
\left(\frac{\text { D.C. } \times \text { B.v. } \times \text { protein } \%}{100^{2}}\right)\end{array}$ \\
\hline$x$ & 17.5 & $76 \cdot 8 \pm I \cdot 62$ & $82 \cdot 0 \pm I \cdot 00$ & $I I \cdot I$ \\
\hline 8 & $26 \cdot 8$ & $87.6 \pm 0.87$ & $70 \cdot 6 \pm 0.93$ & $16 \cdot 6$ \\
\hline 3 & 19.7 & $83.8 \pm 0.53$ & $78.2 \pm 0.91$ & $12 \cdot 8$ \\
\hline 9 & $27 \cdot 7$ & $92 \cdot 8 \pm 1 \cdot 23$ & $74 \cdot 5 \pm x \cdot 70$ & 19.2 \\
\hline 4 & $20 \cdot 0$ & $86.6 \pm 0.57$ & $79 \cdot 0 \pm 1 \cdot 19$ & 13.7 \\
\hline 10 & $27 \cdot 9$ & $87.9 \pm 0.47$ & $70.0 \pm 0.93$ & $17 \cdot 2$ \\
\hline 6 & $22 \cdot 7$ & $87.0 \pm 0.52$ & $79 \cdot 7 \pm 1 \cdot 01$ & 15.7 \\
\hline
\end{tabular}

Table 3. Expt (a). Growth-promoting effects of diets containing high-protein and lowprotein Bengal gram given to rats at the $12 \%$ level of protein intake for 3 weeks

(Mean values for groups of six rats)

\begin{tabular}{|c|c|c|c|c|}
\hline $\begin{array}{c}\text { Pulse } \\
\text { sample } \\
\text { no. }\end{array}$ & $\begin{array}{c}\text { Protein in pulse } \\
(\mathrm{N} \times 6.25) \\
\text { on moisture- } \\
\text { free basis } \\
(\%)\end{array}$ & $\begin{array}{c}\text { Protein } \\
\text { consumed* } \\
\text { (g) }\end{array}$ & $\begin{array}{l}\text { Weight gain* } \\
\text { (g) }\end{array}$ & P.E.R.† \\
\hline I & $17 \cdot 5$ & $\begin{array}{c}14.0 \\
(13.8-14.9)\end{array}$ & $\begin{array}{c}16.0 \\
(15.1-17 \cdot 8)\end{array}$ & $I \cdot 2 \pm 0.04$ \\
\hline 10 & $27 \cdot 9$ & $\begin{array}{c}15 \cdot 1 \\
(14 \cdot 2-15 \cdot 4)\end{array}$ & $\begin{array}{c}26 \cdot 3 \\
(23 \cdot 8-28 \cdot 4)\end{array}$ & $1 \cdot 7 \pm 0.08$ \\
\hline 2 & 17.9 & $\begin{array}{c}14.4 \\
(14 \cdot 0-15 \cdot 2)\end{array}$ & $\begin{array}{c}18 \cdot 0 \\
(16 \cdot 5-20 \cdot 1)\end{array}$ & $x \cdot 3 \pm 0.06$ \\
\hline 7 & $26 \cdot 3$ & $\begin{array}{c}15.3 \\
(14.9-15.6)\end{array}$ & $\begin{array}{c}27 \cdot 0 \\
(25 \cdot 4-28 \cdot 6)\end{array}$ & $1.8 \pm 0.07$ \\
\hline
\end{tabular}

Expt (b). The results are given in Table 4. The values for P.E.R. showed no appreciable variation in nutritional quality between the diets containing the high- and lowprotein Bengal gram. There was also not much difference in the nitrogen or fat content of the livers of the animals given the high- or low-protein pulses.

Expt (c). The results are given in Table 5, from which it will be seen that diets A and $B$, containing pulses with 26.3 and $22.0 \%$ protein respectively, did not differ in growth-promoting ability, as measured by body-weight gain. Diet $\mathrm{B}$, containing the 
gram variety with $22.0 \%$ protein proved slightly better in growth-promoting potency than diet $\mathrm{C}$ with gram of $17.5 \%$ protein content. Analysis showed no appreciable difference in nitrogen or fat content of the liver of rats given diets with high- or lowprotein pulses.

Table 4. Expt (b). Growth-promoting effects of diets containing high-protein and lowprotein Bengal gram supplemented with wheat protein (contributing $5 \%$ protein to the diet) given to rats at a $12 \%$ level of protein intake for 3 weeks

\begin{tabular}{|c|c|c|c|c|c|c|c|c|}
\hline \multirow[b]{3}{*}{$\begin{array}{c}\text { Sample } \\
\text { no. }\end{array}$} & \multirow{3}{*}{$\begin{array}{c}\text { Protein } \\
\text { in pulse } \\
(\mathrm{N} \times 6 \cdot 25) \\
\text { on moisture- } \\
\text { free basis } \\
(\%)\end{array}$} & \multicolumn{5}{|c|}{ (Mean values for groups of six rats) } & \multirow{2}{*}{\multicolumn{2}{|c|}{$\begin{array}{l}\text { Liver content on } \\
\text { moisture-free basis }\end{array}$}} \\
\hline & & \multirow[b]{2}{*}{$\begin{array}{c}\text { Pulse* } \\
\text { in diet } \\
(\%)\end{array}$} & \multirow[b]{2}{*}{$\begin{array}{c}\text { Wheat* } \\
\text { in diet } \\
(\%)\end{array}$} & \multirow[b]{2}{*}{$\begin{array}{l}\text { Protein } \\
\text { consumed } \uparrow \\
(\mathrm{g})\end{array}$} & \multirow[b]{2}{*}{$\begin{array}{c}\text { Weight } \\
\text { gaint } \\
(\mathrm{g})\end{array}$} & \multirow[b]{2}{*}{ P.E.R.f } & & \\
\hline & & & & & & & $\begin{array}{c}\mathrm{N} \\
(\%)\end{array}$ & $\begin{array}{l}\text { Fat } \\
(\%)\end{array}$ \\
\hline 4 & $20 \cdot 0$ & $38 \cdot 6$ & $39 \cdot 5$ & $\begin{array}{c}15 \cdot 6 \\
(14 \cdot 1-16 \cdot 3)\end{array}$ & $\begin{array}{c}31 \cdot 5 \\
26 \cdot 5-33 \cdot 2)\end{array}$ & $\begin{array}{c}2.02 \pm \\
0.08\end{array}$ & $3 \cdot 1$ & $2 \cdot 8$ \\
\hline 8 & $26 \cdot 8$ & $29^{\circ} \mathrm{I}$ & 39.5 & $\begin{array}{c}16 \cdot 1 \\
(14 \cdot 0-19 \cdot 7)\end{array}$ & $\begin{array}{c}34 \cdot 0 \\
3(1 \cdot 1-37 \cdot 8)\end{array}$ & $\begin{array}{l}2.11 \pm \\
0.14\end{array}$ & $3 \cdot 0$ & $2 \cdot 7$ \\
\hline 6 & $22 \cdot 7$ & $34 \cdot 2$ & $39 \cdot 5$ & $\begin{array}{c}I 4 \cdot I \\
(13 \cdot 0-15 \cdot 0)\end{array}$ & $\begin{array}{c}27 \cdot 5 \\
26 \cdot 6-28 \cdot 5)\end{array}$ & $\begin{array}{c}1 \cdot 95 \pm \\
0.08\end{array}$ & $2 \cdot 7$ & $2 \cdot 8$ \\
\hline 9 & $27 \cdot 7$ & $28 \cdot 2$ & $39 \cdot 5$ & $\begin{array}{c}17 \cdot 2 \\
(16 \cdot 1-18 \cdot 0)\end{array}$ & $\begin{array}{c}35 \cdot 0 \\
32 \cdot 1-36 \cdot 4)\end{array}$ & $\begin{array}{c}2.04 \pm \\
0.05\end{array}$ & $2 \cdot 9$ & $2 \cdot 5$ \\
\hline & & & $\begin{array}{l}\text { Air-dri } \\
\text { Value } \\
\text { Value }\end{array}$ & $\begin{array}{l}\text { ange. } \\
\text { a standar }\end{array}$ & fiation. & & & \\
\hline
\end{tabular}

Table 5. Expt (c). Growth-promoting effects of diets containing high-protein and low-protein Bengal gram supplemented with casein given to weanling rats for 3 weeks

\begin{tabular}{|c|c|c|c|c|c|c|c|c|c|c|}
\hline \multirow[b]{2}{*}{ Diet } & \multirow[b]{2}{*}{$\begin{array}{c}\text { Sample } \\
\text { no. }\end{array}$} & \multirow{2}{*}{$\begin{array}{c}\text { Protein } \\
\text { in pulse } \\
(\mathrm{N} \times 6.25) \\
\text { on moisture- } \\
\text { free basis } \\
(\%)\end{array}$} & \multirow[b]{2}{*}{$\begin{array}{c}\text { Pulse* } \\
\text { in diet } \\
(\%)\end{array}$} & \multirow{2}{*}{$\begin{array}{c}\text { Pulse } \\
\text { protein } \\
\text { in diet } \\
(\%)\end{array}$} & \multirow[b]{2}{*}{$\begin{array}{l}\text { Casein* } \\
\text { in diet } \\
(\%)\end{array}$} & \multirow{2}{*}{$\begin{array}{c}\text { Casein } \\
\text { protein } \\
\text { in diet } \\
(\%)\end{array}$} & \multirow{2}{*}{$\begin{array}{c}\text { Total } \\
\text { protein } \\
\text { in diet } \\
(\%)\end{array}$} & \multirow[b]{2}{*}{ P.E.R. $\dagger$} & \multicolumn{2}{|c|}{$\begin{array}{l}\text { Liver content } \\
\text { on moisture- } \\
\text { free basis }\end{array}$} \\
\hline & & & & & & & & & $\begin{array}{c}N \\
(\%)\end{array}$ & $\begin{array}{l}\text { Fat } \\
(\%)\end{array}$ \\
\hline A & 7 & $26 \cdot 3$ & 50 & $11 \cdot 7$ & $7 \cdot 9$ & $6 \cdot 3$ & 18 & $\begin{array}{c}2.80 \pm \\
0.05\end{array}$ & $3 \cdot 4$ & $2 \cdot 6$ \\
\hline B & 5 & $22 \cdot 0$ & 50 & $10 \cdot 0$ & IO' I & $8 \cdot 0$ & 18 & $\begin{array}{c}2 \cdot 75 \pm \\
0.04\end{array}$ & $3 \cdot 5$ & $3 \cdot 1$ \\
\hline $\mathrm{C}$ & I & 17.5 & 50 & $7 \cdot 9$ & $14^{\circ} 0$ & I I.O & 18 & $\begin{array}{c}2.45 \pm \\
0.04\end{array}$ & $3 \cdot 4$ & $2 \cdot 7$ \\
\hline D & I & 17.5 & $74 \cdot 5$ & $11 \cdot 7$ & $7 \cdot 9$ & $6 \cdot 3$ & I8 & $\begin{array}{c}2 \cdot 36 \pm \\
0 \cdot 07\end{array}$ & $3 \cdot 4$ & $2 \cdot 4$ \\
\hline
\end{tabular}

\section{DISCUSSION}

This investigation tended to indicate that a higher content of protein in Bengal gram, brought about by heredity, environment or both, was not necessarily associated with higher overall nutritive value. The slight lowering of biological value with increasing protein content does not seem to be a serious factor with human diets as the 
digestibility and the net protein value tended to increase. The slight difference suggests the possibility of slight differences in the amino-acid composition of the protein which needs further detailed chemical study.

Whether the pulses were given alone or with wheat to supply $12 \%$ protein in the diet, the protein of high-protein Bengal gram was not inferior in promoting bodyweight gain to that of low-protein gram. The practical importance of Expt $(b)$ is that a smaller quantity of high-protein Bengal gram mixed with wheat gave the same P.E.R. as a greater quantity of low-protein Bengal gram.

In Expt (c), both diets (A and B) containing Bengal gram samples with 26.3 and $22.0 \%$ protein respectively were better in growth-promoting ability than diet $\mathrm{C}$, containing the Bengal gram sample with $17.5 \%$ protein. With the first gram a ratio of Bengal gram $\mathrm{N}$ to casein $\mathrm{N}$ of $\mathrm{I}: 0.53(\operatorname{diet} \mathrm{A})$ was better in nutritional quality than a ratio of $1: 1 \cdot 39$ (diet $C$ ) with the last. Diet $A$ was not inferior to diet $B$ in which the ratio of Bengal gram $N$ to casein $N$ was $1: 0 \cdot 80$. These results tend to indicate a superior nutritional quality for the high-protein Bengal gram. When diets $\mathrm{A}$ and $\mathrm{D}$ containing Bengal gram samples with 26.3 and $17.5 \%$ protein respectively and an equal quantity of casein protein $(6.3 \%)$ were compared, the P.E.R. was found to be higher with high-protein Bengal gram pulse, which gives additional weight to this conclusion.

As regards the practical aspects of the study, it will be seen that the protein of the high-protein Bengal gram was in no way inferior to that in low-protein samples and may have been superior. This finding suggests that it would be a sound policy to grow Bengal gram under optimum conditions of strain and environment that would ensure a higher protein content.

Further work on fractionation of proteins, amino-acid distribution and the nature and amount of non-protein $\mathrm{N}$ in both high- and low-protein Bengal gram samples is in progress.

\section{SUMMAR Y}

I. The digestibility and biological value of proteins in high- and low-protein Bengal gram were studied by the balance-sheet method at a 12 \% protein level with adult albino rats. The results tended to indicate that though the biological value of the proteins of the high-protein Bengal gram pulse was slightly less, its digestibility was slightly higher and the net protein value remained at the higher level.

2. The protein efficiency ratio (P.E.R.) of both high- and low-protein Bengal gram pulses was assessed also at the $12 \%$ protein level by giving diets containing Bengal gram either as the sole source of protein or supplemented with wheat to weanling albino rats. When Bengal gram was given as the sole source of protein the P.E.R. found with the high-protein gram was slightly higher than that with the low-protein sample. In the diet supplemented with wheat, the high- and low-protein samples had almost equal P.E.R.'s.

3. When pulse samples of different protein content were supplemented with casein so that the diet contained I $8 \%$ protein, the high-protein sample tended to be slightly superior in nutritional quality to the low-protein sample. 
Our thanks are due to several State Agricultural Farms for supplying the authentic samples for this study.

\section{REFERENCES}

Basu, K. P., Nath, M. C. \& Mukherjee, R. (1937). Indian F. med. Res. 24, I00I.

Dobbins, F. A., Krider, J. L., Hamilton, T. S., Earley, E. B. \& Terrill, S. W. (1950a). F. Anim. Sci. 9, 625 .

Dobbins, F. A., Krider, J. L., Hamilton, T. S., Earley, E. B. \& Terrill, S. W. (1950b). F. Anim. Sci. 9,654 .

Esh, G. C., De, T. S. \& Basu, U. P. (1959). Science, 129, 148.

Esh, G. C. \& Som, J. M. (1952). F. Physiol, and Allied Sci. 6, 6r.

Hansen, D. W., Brimhall, B. \& Sprague, G. F. (1946). Cereal Chem. 23, 329.

Hawk, E. A. \& Elvehjem, C. A. (I953). F. Nutr. 49, 495.

Hogan, A. G., Gillespie, G. T., Koçtürk, O., O’Dell, B. L. \& Flynn, L. M. (1955). F. Nutr. 57, 225 .

Mitchell, H. H. (1923-4). F. biol. Chem. 58, 873 .

Mitchell, H. H. \& Carman, G. C. (1926). F. biol. Chem. 68, 183.

Mitchell, H. H., Hamilton, T. S. \& Beedles, J. R. (1952). F. Nutr. 48, $46 \mathrm{r}$.

Niyogi, S. P., Narayan, N. \& Desai, B. G. (1932a). Indian F. med. Res. 19, 475.

Niyogi, S. P., Narayan, N. \& Desai, B. G. (1932b). Indian $¥$. med. Res. 19, 104I.

Ross, C. V., Garrigus, U. S., Hamilton, T. S. \& Earley, E. B. (1952). F. Anim. Sci. II, 774.

Sauberlich, H. E., Chang, W. \& Salmon, D. (1953a). F. Nutr. 5I, 24I.

Sauberlich, H. E., Chang, W. \& Salmon, D. (1953b). F. Nutr. 5I, 623. 